\title{
Sand mining disturbances and their effects on the diversity of arbuscular mycorrhizal fungi in a riparian forest of Iran
}

\author{
Sareh MORADI BEHBAHANI ${ }^{1}$, Mostafa MORADI ${ }^{1 *}$, Reza BASIRI ${ }^{1}$, Javad MIRZAEI ${ }^{2}$ \\ ${ }^{1}$ Department of Forestry, Faculty of Natural Resources and Environment, Behbahan Khatam Al-Anbia University of \\ Technology, Behbahan 6361647189, Iran; \\ ${ }^{2}$ Department of Forest Science, Faculty of Agriculture, Ilam University, Ilam 69315516, Iran
}

\begin{abstract}
The major objective of this study was to evaluate the effects of sand mining disturbances on the diversity of arbuscular mycorrhizal fungi (AMF). In addition, the proportional changes in the diversity of AMF to the distances from riverbanks were assessed. For this purpose, the riparian forest of the Maroon River, Iran was divided into three locations with a 200-meter wide zone in between. Thus, the locations studied were named Distance I (riverbank), Distance II (intermediate), and Distance III (farthest from riverbank). In each of these distances, 10 Tamarix arceuthoides and Populus euphratica of each species were randomly selected. At the same time, soil and root samples were collected from the rhizosphere of the tree species studied. Results indicated that totally 13 AMF species were observed in T. arceuthoides and 19 AMF species were recorded in $P$. euphratica rhizosphere belonging to 6 genera and 6 families. In these AMF species, Glomus segmentatum, G. geosporum, G. rubiforme, G. nanolumen, G. spinuliferum, Claroideoglomus drummondii, Gigaspora gigantea and Acaulospora paulinae appeared only in P. euphratica rhizosphere, while G. multiforum and Claroideoglomus claroideum were observed only in T. arceuthoides rhizosphere. Moreover, Distance II had the least AMF species both in T. arceuthoides and in P. euphratica rhizospheres, and also the least spore density and root colonization rate. Our results are important in that they provide a list of resistant AMF species that could be used in the conservation of biodiversity.
\end{abstract}

Keywords: arbuscular mycorrhizal; disturbance; riparian forest; sand mining; Maroon River

Citation: Sareh MORADI BEHBAHANI, Mostafa MORADI, Reza BASIRI, Javad MIRZAEI. 2017. Sand mining disturbances and their effects on the diversity of arbuscular mycorrhizal fungi in a riparian forest of Iran. Journal of Arid Land, 9(6): 837-849. https://doi.org/10.1007/s40333-017-0028-0

\section{Introduction}

Riparian forests maintain a chain of important ecological functions, including water purification, flooding control, and natural habitat and biodiversity conservation (Burton, 2006; Harris and Koucher, 2007; Strasser et al., 2014). Nevertheless, they are among the most endangered ecosystems in the world (Tockner and Stanford, 2002). Khuzestan, a southwestern province of Iran, is well known as a home to major rivers and abundant fresh water resources. The littoral lands beside Khuzestan's riverbanks are covered by riparian forests, mostly composed of Populus euphratica and Tamarix arceuthoides (Browicz, 1977). These riparian forests, with a high floral diversity (Sakio and Tamura, 2008), are crucial for ecological health in this arid area (Isebrands

\footnotetext{
*Corresponding author: Mostafa MORADI (E-mail: moradi4@gmail.com)

Received 2016-07-27; revised 2017-07-04; accepted 2017-07-07

CC Xinjiang Institute of Ecology and Geography, Chinese Academy of Sciences, Science Press and Springer-Verlag GmbH Germany 2017
} 
and Richardson, 2014). In spite of the importance of these riparian forests, little is known regarding the ecological information.

There are several factors causing the degradation of these vulnerable ecosystems, including the invasion of exotic plant species (Naiman et al., 2000), environmental pollution (Tockner and Stanford, 2002) and sand mining (Tockner and Stanford, 2002; Lawal et al., 2011; Sreebha and Padmalal, 2011; Bravard et al., 2013). It is worthy noting that sand mining has been noted to be among the most devastating factors due to the over-exploitation for sand and gravel all over the world. Researchers have found that sand mining may result in the loss of riparian forest (Padmalal et al., 2008), depletion of vegetation, water pollution (Byrnes and Hiland, 1995; Ashraf et al., 2011), landscape disturbance (Lawal et al., 2011) and many other negative effects (Ashraf et al., 2011). However, there is very little available information on the effect of sand disturbances on soil microorganisms, such as the diversity of arbuscular mycorrhizal fungi (AMF) in these ecosystems.

AMF are soil-borne microbial communities that form mutualistic symbioses with terrestrial plants (Smith and Read, 2008). They belong to the fungal phylum Glomeromycota (Schüßler et al., 2001). These fungi are known to be important for the stability and productivity of ecosystems (van der Heijden et al., 2008). Furthermore, they are crucial for the initiation of vegetation (Caravaca et al., 2003; Quoreshi, 2008). Yet, it should be pointed out that these fungal communities are likely to be affected by vegetation, soil $\mathrm{CaCO}_{3}$, land use, and disturbance (Jha et al., 1992; Lambin et al., 2003; Oehl et al., 2011; Moradi et al., 2015). Therefore, these fungal communities can be used as soil quality indicators (Oehl et al., 2011; Verbruggen et al., 2012).

Recently, researchers have found that AMF can form mutualistic symbioses with some riparian plant species, such as P. euphratica and Tamarix spp. (Yang et al., 2008). The infection rate and status of AMF in riparian forest species were affected by their soil chemical properties (Shi et al., 2006; Yang et al., 2008; Moradi et al., 2017). Furthermore, it has been demonstrated that AMF spore density, root colonization, and diversity are different in these riparian forests (Beauchamp et al., 2005; Wang et al., 2010; Lehnhoff et al., 2012; Yang et al., 2013). Therefore, we hypothesize that the responses of AMF in different riparian forests to sand mining disturbances are species-dependent. Our aim of the study is to evaluate the effect of sand mining and truck movements on the diversity of AMF in a riparian forest dominated by P. euphratica and $T$. arceuthoides in Khuzestan, Iran.

\section{Materials and methods}

\subsection{Study area}

This study was conducted in the riparian forest of Maroon River in Behbahan within Iran's southern Khuzestan Province. The study site was located at $32^{\circ} 38^{\prime} 53^{\prime \prime}-30^{\circ} 39^{\prime} 30^{\prime \prime} \mathrm{N}$ and $50^{\circ} 09^{\prime} 30^{\prime \prime}-50^{\circ} 10^{\prime} 25^{\prime \prime} \mathrm{E}$ with an average elevation of 250-300 $\mathrm{m}$ a.s.l. (Fig. 1). The average annual precipitation and annual mean temperature of the site were $350 \mathrm{~mm}$ and $24^{\circ}$, respectively. This site was typically dominated by $P$. euphratica and $T$. arceuthoides with a floral coverage by other species like Lycium sp. and Vitex pseudonegundo to a lesser degree.

\subsection{Sampling method}

The riparian forest along the width direction was divided into three zones with a 200-meter wide zone in between. The locations studied were named Distance I (riverbank), Distance II (intermediate), and Distance III (furthest from riverbank). The reason behind this division was that sand mining and truck movements took place within Distance II. To differentiate the distance effect from the disturbance effect, we have left 50 meters as a buffering zone between each of the distances studied. On the other hand, we have left 50 meters before and after sand mining locations as a buffering zone (Fig. 1). Since the dominant species in this riparian forest were $P$. euphratica and $T$. arceuthoides, we randomly selected 10 trees from each species per studied 
distance (in total 60 samples, 30 samples for each species). Rhizosphere samples were taken from a depth of $15 \mathrm{~cm}$ after litter removal in spring (Moradi et al., 2015). These soil samples were used for spore extraction and the determination of soil physical-chemical properties.

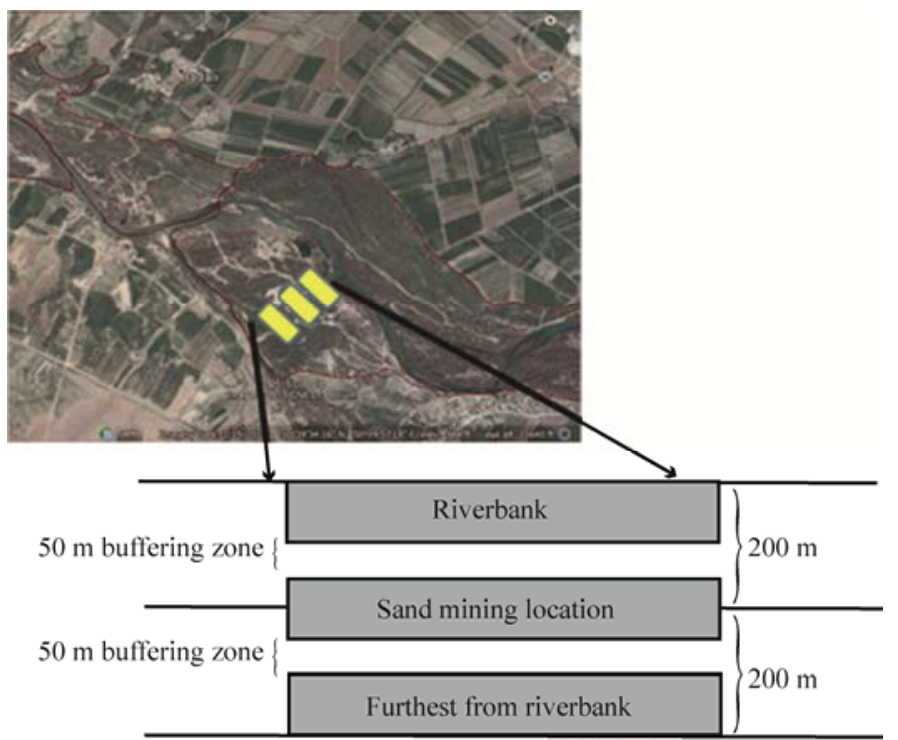

Fig. 1 Location of study site and sampling design

\subsection{AMF spore extraction and identification}

Spores were extracted from the soil by wet sieving and decanting (Gerdemann and Nicolson, 1963), followed by centrifugation in water. Sieve sizes ranged from 38 to $500 \mu \mathrm{m}$. Five grams of the rhizosphere soil of the plant species studied were used in extracting spores. All extracted spores were mounted on slides stained with PVLG (polyvinyl alcohol lactic acid glycerol), as well as PVLG with Melzer reagent. The identification procedure was based on the observation of morphological features like spore walls, colors and sizes using a stereomicroscope (Olympus CH-2) and in accordance with Schenck and Perez (1988).

\subsection{Soil analysis}

All soil samples were air-dried and passed through a 2-mm sieve. Soil phosphorus (P) (Olsen et al., 1954), exchangeable potassium (K) (Morwin and Peach, 1951), nitrogen (N) (Bremner and Mulvaney, 1982), organic carbon (OC) (Walkley and Black, 1934), pH (deionized water suspension of 1:2.5) and textures (hydrometric) were determined. Soil moisture content was determined using oven drying at $105^{\circ} \mathrm{C}$ for $24 \mathrm{~h}$.

\subsection{Diversity indices}

AMF diversities were evaluated using the Shannon-Weiner indices of diversity $\left(\mathrm{H}^{\prime}\right)$, evenness, Simpson's index of dominance, and Margalef's richness index (Eqs. 1-4).

$$
H^{\prime}=-\sum P_{i} \ln P_{i}
$$

where $P_{i}$ is the relative abundance of each identified species per sampling site.

Evenness (E) was calculated by Equation 2:

$$
E=\frac{H^{\prime}}{H_{\max }},
$$

where $H_{\max }=\log _{2}(S)$, and $S$ is the total number of species.

Simpson's index of dominance (D) was calculated by Equation 3:

$$
D=\sum\left[n_{i}\left(n_{i}-1\right) / N(N-1)\right]
$$

where $n_{i}$ is the number of spores of a species and $N$ is the total number of identified spore 
samples.

Margalef's richness index $\left(\mathrm{D}_{\mathrm{m}}\right)$ was calculated by Equation 4 :

$$
D_{m}=\frac{S-1}{\ln (N)},
$$

where $S$ is the number of species.

\subsection{Data analysis}

All data were subjected to normality tests and analyzed using one-way ANOVA to determine any differences between diversity indices and physical-chemical soil properties within the denoted distances. If data were significantly different, a pairwise comparison was conducted using the Duncan's post hoc analysis. Moreover, the Pearson's correlation coefficient was used to determine any significant correlation between the soil parameters and AMF diversity indices. All the analyses mentioned were performed by SPSS 16.0 software. Furthermore, principal component analysis (PCA) was performed to obtain the most important factors on AMF diversity. To evaluate the effects of soil physical-chemical properties, we applied redundancy analysis (RDA) with Monte Carlo (unrestricted 999 permutations) to verify the relationship between AMF diversity indices and soil physical-chemical properties. This analysis was performed using the CANOCO for Windows version 4.5. Also, PC-ORD for Windows (V.5) (McCune and Mefford, 1999) was used to determine the keystone species in the study field.

\section{Results and discussion}

\subsection{AMF diversity}

The results indicate that there were 21 AMF species belonging to 6 genera and 6 families in the riparian forest (Table 1). Thirteen species were observed in the T. arceuthoides rhizosphere and 19 in the P. euphratica rhizosphere. As shown in Table 1, Glomus segmentatum, G. geosporum, G. rubiforme, G. nanolumen, G. spinuliferum, Claroideoglomus drummondii, Gigaspora gigantea and Acaulospora paulinae appeared only in the $P$. euphratica rhizosphere. Meanwhile, $G$. multiforum and C. claroideum occurred in Tamarix sp. rhizosphere (Table 1). Glomus was the most frequent genus observed in stands of $T$. arceuthoides and $P$. euphratica, being consistent with the finding of Börstler et al. (2008). It should be noted that some AMF species are plant species-specific for $T$. arceuthoides and $P$. euphratica. The reason for this may be related to health of host plants and/or soil conditions that may affect AMF diversity (Chaudhary et al., 2008). Another reason for this may be due to genetic differences among different AMF species, since such a difference could affect the survivals or functionalities of AMF and their host plants (Colard et al., 2011).

The T. arceuthoides rhizosphere had 9, 6, and 11 AMF species detected in Distances I, II, and III, respectively, while they were respectively 11, 9, and 13 AMF species in the P. euphratica rhizosphere, indicating that Distance III (i.e., the farthest research zone from the riverside) had the highest AMF, while Distance II or the zone severely disturbed by sand mining had the least AMF. Moreover, G. geosporum and G. rubiforme were AMF species that were only detected in the $P$. euphratica rhizosphere within the boundaries of Distance II. It means that the tolerance of these AMF to disturbance may be useful for later restoration activities (Lara-Pérez et al., 2014). We also found that $F$. badium, $F$. constrictum, and $C$. etunicatum were among AMF whose frequency remained unaffected by the distance from the riverside and the location of sand mining. This result may indicate that these fungi have adapted well to these anthropogenic disturbances. In contrast, the distance from both the riverside and the sand mining had negative effects on the frequencies of $F$. mossea, $G$. gibbosum, $G$. nanolumen, $G$. spinuliferum, $C$. drummondii, A. trappei, and $P$. fransiscana (Table 1). These AMF may well be the indicators of land degradation (Kennedy and Papendick, 1995). Based on this study, a list of AMF species can be proposed both 
for disturbed and for non-disturbed distances. This kind of list can be important because it may be helpful for site restoration (Symanczik et al., 2014).

Table 1 AMF and their frequencies (\%) within the designated distances



$F$. badium and G. gibbosum were identified as the keystone indicator species at Distance III, while no keystone species were found at the other two distances in the P. euphratica stand (Table 2). It is well documented that AMF are keystone soil micro-organisms for the conservation of biodiversity (O’Neill et al., 1991; Power and Mills, 1995; Piraino et al., 2002). The lowest frequency of G. gibbosum at Distance II (i.e., the severely disturbed distance) indicated that the negative effects of sand mining on keystone species are rather pronounced. Our results are important in that they provide a list of resistant AMF species that could be used in the conservation of biodiversity.

In the $T$. arceuthoides stand, G. gibbosum and $C$. etunicatum were considered as keystone species in Distance I and Distance II, respectively (Table 3). This finding is consistent with the findings of Piraino et al. (2002), who provided evidence that $C$. etunicatum occurred in a highly disturbed environment. Different AMF keystone species found in $P$. euphratica and $T$. arceuthoides stands reflect not only the differences in responses to plant species but also the AMF symbiosis to anthropogenic activity.

The changes of AMF species by anthropogenic regimes suggest that AMF is a good indicator of soil quality changes, being consistent with the findings of Verbruggen et al. (2012).

\subsection{Principal component analysis (PCA)}

The PCA results for $T$. arceuthoides indicated that the first and second axes explained $48.80 \%$ and $23.46 \%$ of total variance, respectively (Fig. 2). Furthermore, the results of Monte Carlo permutation tests on redundancy analysis (RDA) showed that soil sand, silt, moisture, clay, and 
phosphorus (P) are the most important factors affecting AMF diversity in $T$. arceuthoides (Table 4). The PCA result for $P$. euphratica revealed that the first and second axes explained $69.27 \%$ and $19.71 \%$ of the total variance, respectively (Fig. 3). The Monte Carlo permutation tests on RDA indicated that the most significant affecting factors in the physical-chemical properties of soil on AMF diversity in P. euphratica stands are soil moisture, clay, and $\mathrm{pH}$ (Table 5). Our results are consistent with Deepika and Kothamasi (2015). These results imply that soil-property changes caused by anthropogenic activity can result in significant AMF changes. Furthermore, it implies that sand mining disturbance affects AMF directly and indirectly by changing either soil conditions or the status of host plant roots.

Table 2 Keystone indicator species for P. euphratica stand

\begin{tabular}{|c|c|c|c|}
\hline AMF species & Distance & Importance value index & $P$ value \\
\hline Glomus arenarium & \multirow{6}{*}{ I } & 39.3 & 0.3997 \\
\hline Pacispora fransiscana & & 17.1 & 0.5381 \\
\hline Glomus caesaris & & 10.0 & 1.0000 \\
\hline Gigaspora margarita & & 10.0 & 1.0000 \\
\hline Acaulospora paulinae & & 10.0 & 1.0000 \\
\hline Gigaspora gigantean & & 10.0 & 1.0000 \\
\hline Claroideoglomus etunicatum & \multirow{3}{*}{ II } & 35.9 & 0.7269 \\
\hline Glomus geosporum & & 10.0 & 1.0000 \\
\hline Glomus rubiforme & & 10.0 & 1.0000 \\
\hline Funneliformis badium & \multirow{10}{*}{ III } & 53.3 & 0.0116 \\
\hline Glomus gibbosum & & 44.6 & 0.0270 \\
\hline Funneliformis constrictum & & 40.9 & 0.1576 \\
\hline Archaeospora trappei & & 36.0 & 0.1526 \\
\hline Funneliformis mossea & & 20.0 & 0.3069 \\
\hline Glomus deserticola & & 20.0 & 0.3143 \\
\hline Glomus nanolumen & & 10.0 & 1.0000 \\
\hline Glomus spinuliferum & & 10.0 & 1.0000 \\
\hline Claroideoglomus drummondii & & 10.0 & 1.0000 \\
\hline Glomus segmentatum & & 7.5 & 0.7487 \\
\hline
\end{tabular}

Table 3 Keystone indicator species for T. arceuthoides stand

\begin{tabular}{|c|c|c|c|}
\hline AMF species & Distance & Importance value index & $P$ value \\
\hline Glomus gibbosum & \multirow{4}{*}{ I } & 39.6 & 0.0176 \\
\hline Funneliformis badium & & 36.6 & 0.8344 \\
\hline Gigaspora margarita & & 10.0 & 1.0000 \\
\hline Glomus multiforum & & 10.0 & 1.0000 \\
\hline Claroideoglomus etunicatum & \multirow{2}{*}{ II } & 41.6 & 0.0236 \\
\hline Glomus arenarium & & 38.5 & 0.4445 \\
\hline Funneliformis constrictum & \multirow{7}{*}{ III } & 39.9 & 0.2180 \\
\hline Archaeospora trappei & & 24.0 & 0.7704 \\
\hline Claroideoglomus claroideum & & 20.0 & 0.3137 \\
\hline Pacispora fransiscana & & 20.0 & 0.3001 \\
\hline Glomus segmentatum & & 10.0 & 1.0000 \\
\hline Glomus deserticola & & 10.0 & 1.0000 \\
\hline Funneliformis mossea & & 7.0 & 1.0000 \\
\hline
\end{tabular}




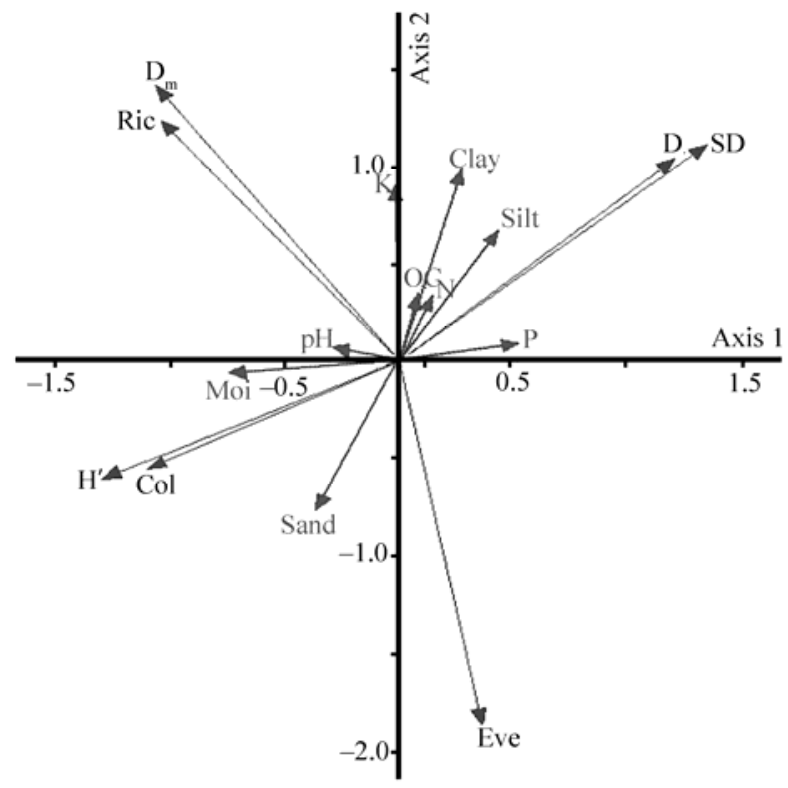

Fig. 2 Principal component analysis of AMF diversity indices and soil physical-chemical properties in $T$. arceuthoides rhizosphere. SD, spore density; D, Simpson's index of dominance; Ric, richness; $\mathrm{D}_{\mathrm{m}}$, Margalef's richness index; Col, colonization; H', Shannon-Weiner indices of diversity; N, nitrogen; OC, organic carbon; K, potassium; P, phosphorus; Moi, moisture; Eve, evenness.

Table 4 Monte Carlo permutation test on redundancy analysis for soil physical-chemical properties of $T$. arceuthoides

\begin{tabular}{ccc}
\hline Soil physical-chemical property & $F$ value & $P$ value \\
\hline Sand & 15.572 & 0.002 \\
Silt & 15.413 & 0.005 \\
Moisture & 14.062 & 0.003 \\
Clay & 10.360 & 0.008 \\
Phosphorus & 4.715 & 0.040 \\
Organic carbon & 4.393 & 0.060 \\
Nitrogen & 4.342 & 0.070 \\
Potassium & 1.749 & 0.200 \\
pH & 0.007 & 0.980 \\
\hline
\end{tabular}

\subsection{Spore density (SD) and root colonization rate}

The SD associated with the $T$. arceuthoides rhizosphere in Distance II, where sand mining and truck movements occurred, had the highest significant value (Table 6). Nevertheless, no significant difference was observed in SD values with regard to $P$. euphratica (Table 7). The higher SD in Distance II may be explained by soil compaction that reduced root growth (Wallace, 1987; Trejo et al., 2016). In the present study, P. euphratica and T. arceuthoides showed different SD and root colonization rates, reflecting the fact that different plant species respond differently to these two factors ( $\mathrm{Li}$ et al., 2007).

Furthermore, a high level of symbioses was observed between AMF and P. euphratica, being in accordance with the findings of Wang et al. (2010). Yet, our results are not in accordance with those of Yang et al. (2013) who reported a significantly lower SD in P. euphratica rhizospheres. The reason for a significantly higher level of SD in the current study may be attributable to a higher AMF diversity compared to Yang et al. (2013). The minimum and maximum colonization rates for $T$. arceuthoides and P. euphratica were observed at Distances II and III, respectively 
(Table 6). A clear indication of the negative effect of sand mining and truck movement was found on root colonization rates at Distance II. Changes in SD and root colonization may be induced by soil physical-chemical changes caused by sand mining activity. This study provides a much improved understanding of the impact of sand mining on AMF diversity, colonization, and SD.

An increasing trend in the root colonization rate with increasing distance from the river was observed in the present study, which probably indicates that soil conditions were improved for AMF symbiosis farther from the river. High level of root colonization in this study is in agreement with the findings of Wang et al. (2010).

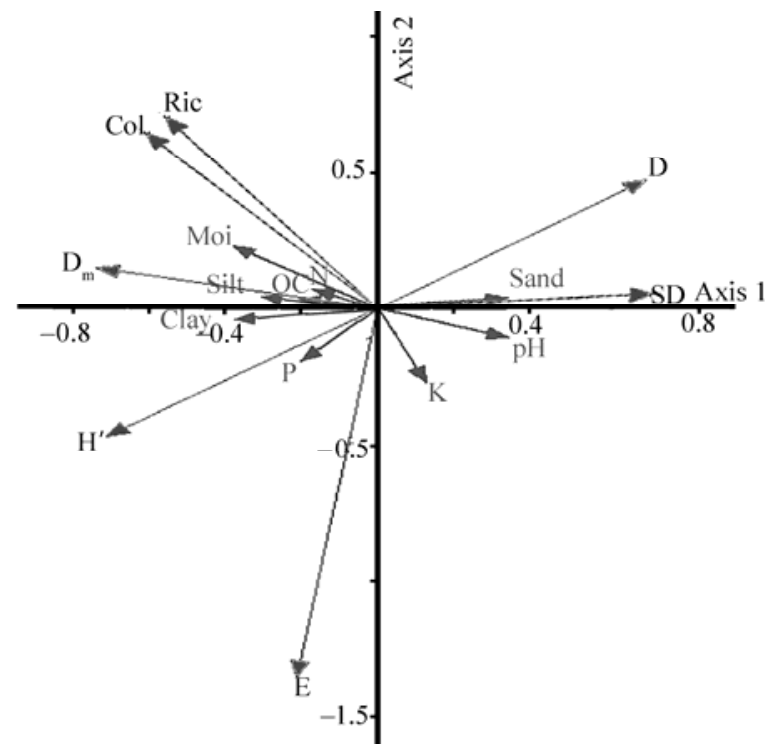

Fig. 3 Principal component analysis of AMF diversity indices and soil physical-chemical properties in $P$. euphratica rhizosphere. SD, spore density; D, Simpson's index of dominance; Ric, richness; $\mathrm{D}_{\mathrm{m}}$, Margalef's richness; Col, colonization; $\mathrm{H}^{\prime}$, Shannon-Weiner indices of diversity; E, Evenness; N, nitrogen; OC, organic carbon; K, Potassium; P, phosphorus; Moi, moisture.

Table 5 Monte Carlo permutation test on redundancy analysis for soil physical-chemical properties of $P$. euphratica

\begin{tabular}{|c|c|c|}
\hline Soil physical-chemical property & $F$ value & $P$ value \\
\hline Moisture & 5.671 & 0.03 \\
\hline Clay & 4.786 & 0.04 \\
\hline $\mathrm{pH}$ & 4.082 & 0.04 \\
\hline Sand & 3.549 & 0.08 \\
\hline Organic carbon & 3.247 & 0.09 \\
\hline Silt & 2.998 & 0.11 \\
\hline Nitrogen & 2.768 & 0.13 \\
\hline Potassium & 2.628 & 0.13 \\
\hline Phosphorus & 0.913 & 0.37 \\
\hline
\end{tabular}

\subsection{Diversity indices}

T. arceuthoides stand had the least AMF diversity at Distance II (Table 6) and P. euphratica stand had the highest AMF diversity at Distanced III (Table 7). Although, Shannon-Weiner indices of diversity $\left(\mathrm{H}^{\prime}\right)$ and Simpson's index of dominance (D) displayed no significant differences between the triple designated Distances, the least significant D was observed in Distance II (Tables 6 and 7). The reason for this is that D is affected by species richness (Magurran, 2004) and higher species richness results in a higher D value (Mahecha-Vásquez et al., 2017). As the 
least species richness was observed in Distance II and then the least D was also observed in this zone (Stürmer and Siqueira, 2011). These results suggest that the impact of sand mining was severe enough to have negatively affected AMF diversity in riparian forest. Sand mining resulted in changes in AMF diversity and composition, and this knowledge is crucial to the understanding of mycorrhizal function in these ecosystems (Soka and Ritchie, 2014a, b).

In addition, distance from the local river also affected AMF diversity, while Distance III (the farthest distance from the river) hosted the highest AMF diversity. This may be due to the least negative effects of natural phenomena among the three distances.

Table 6 AMF diversity for T. arceuthoides stand

\begin{tabular}{|c|c|c|c|}
\hline & Distance I & Distance II & Distance III \\
\hline Root colonization & $82.4 \pm 1.98^{\mathrm{a}}$ & $73.7 \pm 2.89^{\mathrm{b}}$ & $84.4 \pm 2.54^{\mathrm{a}}$ \\
\hline SD & $189 \pm 19.60^{\mathrm{b}}$ & $254 \pm 19.54^{\mathrm{a}}$ & $189 \pm 19.23^{b}$ \\
\hline Richness & $5.4 \pm 0.37^{\mathrm{a}}$ & $4.4 \pm 0.16^{\mathrm{b}}$ & $5.2 \pm 0.38^{\mathrm{ab}}$ \\
\hline $\mathrm{H}^{\prime}$ & $0.84 \pm 0.07^{\mathrm{a}}$ & $0.75 \pm 0.08^{\mathrm{a}}$ & $0.95 \pm 0.05^{\mathrm{a}}$ \\
\hline $\mathrm{D}$ & $0.59 \pm 0.04^{\mathrm{a}}$ & $0.62 \pm 0.05^{\mathrm{a}}$ & $0.51 \pm 0.04^{\mathrm{a}}$ \\
\hline E & $0.45 \pm 0.04^{\mathrm{a}}$ & $0.50 \pm 0.04^{\mathrm{a}}$ & $0.53 \pm 0.05^{\mathrm{a}}$ \\
\hline $\mathrm{D}_{\mathrm{m}}$ & $0.85 \pm 0.06^{\mathrm{a}}$ & $0.62 \pm 0.03^{\mathrm{b}}$ & $0.81 \pm 0.07^{\mathrm{a}}$ \\
\hline
\end{tabular}

Note: SD, Spore density per 5 grams of soil; $\mathrm{H}^{\prime}$, Shannon-Weiner indices of diversity; D, Simpson's index of dominance; E, Evenness; $\mathrm{D}_{\mathrm{m}}$, Margalef's richness index. Different lowercase letters indicate significance among three distances at $P<0.05$ level. Abbreviations are the same as in Table 7.

Table 7 AMF diversity for $P$. euphratica stand

\begin{tabular}{|c|c|c|c|}
\hline & Distance I & Distance II & Distance III \\
\hline Root colonization & $85.5 \pm 1.52^{\mathrm{a}}$ & $65.3 \pm 4.24^{\mathrm{b}}$ & $86.4 \pm 1.56^{\mathrm{a}}$ \\
\hline SD & $174 \pm 22.71^{\mathrm{a}}$ & $177 \pm 24.63^{\mathrm{a}}$ & $186 \pm 15.96^{\mathrm{a}}$ \\
\hline Richness & $5.2 \pm 0.29^{b}$ & $4.3 \pm 0.26^{\mathrm{c}}$ & $6.1 \pm 0.34^{\mathrm{a}}$ \\
\hline $\mathrm{H}^{\prime}$ & $0.91 \pm 0.07^{\mathrm{a}}$ & $0.84 \pm 0.08^{\mathrm{a}}$ & $1.06 \pm 0.09^{\mathrm{a}}$ \\
\hline $\mathrm{D}$ & $0.54 \pm 0.04^{\mathrm{a}}$ & $0.57 \pm 0.05^{\mathrm{a}}$ & $0.48 \pm 0.05^{\mathrm{a}}$ \\
\hline $\mathrm{E}$ & $0.50 \pm 0.04^{\mathrm{a}}$ & $0.55 \pm 0.03^{\mathrm{a}}$ & $0.49 \pm 0.04^{\mathrm{a}}$ \\
\hline $\mathrm{D}_{\mathrm{m}}$ & $0.83 \pm 0.05^{\mathrm{a}}$ & $0.65 \pm 0.05^{\mathrm{b}}$ & $0.97 \pm 0.06^{\mathrm{a}}$ \\
\hline
\end{tabular}

\subsection{Correlation between soil physical-chemical properties and AMF diversity indices}

Pearson's correlation between soil factors and AMF diversity indices at the P. euphratica stand revealed that AMF richness had a positive correlation with soil $\mathrm{P}$ and a negative correlation with $\mathrm{pH}$. However, evenness had a significant negative correlation with richness, Simpson's index of dominance (D) and Margalef's richness index $\left(\mathrm{D}_{\mathrm{m}}\right)$. Furthermore, soil moisture had significant negative correlations with root colonization and AMF richness, while, had a negative significant correlation with spore density (SD) (Table 8). However, for the T. arceuthoides stand, AMF richness had a significantly positive correlation with root colonization (RC). Soil phosphorus (P) had a significantly positive correlation with $\mathrm{D}$ and a significantly negative correlation with Shannon-Weiner indices of diversity $\left(\mathrm{H}^{\prime}\right)$. Yet, Margalef's richness index $\left(\mathrm{D}_{\mathrm{m}}\right)$ was significantly correlated with root colonization. Also, soil moisture had a significantly positive correlation with root colonization (RC) and a significantly negative correlation with SD (Table 9). These results indicate the importance of better soil conditions for higher AMF diversity (Mirzaei and Moradi, 2017). Also, in this study, Distance III with better soil conditions and less anthropogenic activities had higher AMF diversity.

Several factors were reported to have affected AMF diversity, such as environmental (Moradi et al., 2015) and soil conditions (Yang et al., 2011). But in the present study, sand mining and truck movement were documented to have resulted in AMF variations. Also, soil $\mathrm{P}$ and $\mathrm{pH}$ affect AMF diversity, being in line with the findings of other studies (Treseder, 2004; Yoshimura et al., 2013). Being similar to previous studies highlighting the use of AMF species as soil bio-indicators 
Table 8 Pearson's correlation between soil parameters and AMF diversity indices at P. euphratica stand

\begin{tabular}{|c|c|c|c|c|c|c|c|c|c|c|c|c|c|c|c|c|}
\hline & $\mathrm{N}$ & $\mathrm{OC}$ & $\mathrm{P}$ & $\mathrm{K}$ & Clay & Silt & Sand & $\mathrm{pH}$ & Moi & $\mathrm{RC}$ & SD & $\mathrm{R}$ & $\mathrm{D}$ & $\mathrm{H}^{\prime}$ & E & $\mathrm{D}_{\mathrm{m}}$ \\
\hline $\mathrm{N}$ & 1.00 & & & & & & & & & & & & & & & \\
\hline $\mathrm{OC}$ & $0.96^{* *}$ & 1.00 & & & & & & & & & & & & & & \\
\hline $\mathrm{P}$ & 0.36 & 0.26 & 1.00 & & & & & & & & & & & & & \\
\hline $\mathrm{K}$ & -0.01 & -0.05 & 0.48 & 1.00 & & & & & & & & & & & & \\
\hline Clay & 0.20 & 0.20 & $0.66^{* *}$ & 0.16 & 1.00 & & & & & & & & & & & \\
\hline Silt & 0.16 & 0.17 & 0.51 & 0.15 & $0.95^{* *}$ & 1.00 & & & & & & & & & & \\
\hline Sand & -0.17 & -0.18 & $-0.56^{*}$ & -0.16 & $-0.97^{* *}$ & $-0.99^{* *}$ & 1.00 & & & & & & & & & \\
\hline $\mathrm{pH}$ & -0.26 & -0.21 & -0.26 & 0.36 & $-0.52^{*}$ & -0.47 & 0.49 & 1.00 & & & & & & & & \\
\hline Moi & 0.28 & 0.30 & -0.23 & -0.48 & 0.04 & 0.15 & 0.13 & -0.53 & 1.00 & & & & & & & \\
\hline $\mathrm{RC}$ & 0.36 & 0.37 & 0.24 & -0.04 & 0.37 & 0.35 & -0.37 & -0.12 & $0.72^{* *}$ & 1.00 & & & & & & \\
\hline $\mathrm{SD}$ & -0.14 & -0.18 & 0.12 & -0.37 & 0.11 & 0.04 & -.062 & -0.11 & $-0.69^{* *}$ & -0.16 & 1.00 & & & & & \\
\hline $\mathrm{R}$ & 0.36 & 0.27 & $0.57^{*}$ & 0.17 & 0.48 & 0.42 & -0.44 & $-0.58^{*}$ & $0.61^{*}$ & 0.06 & 0.17 & 1.00 & & & & \\
\hline D & 0.06 & 0.21 & -0.24 & -0.26 & -0.01 & -0.06 & 0.05 & 0.18 & -0.48 & 0.30 & 0.16 & -0.27 & 1.00 & & & \\
\hline $\mathrm{H}^{\prime}$ & 0.04 & -0.12 & 0.34 & 0.29 & 0.12 & 0.15 & -0.14 & -0.29 & 0.46 & -0.25 & -0.14 & 0.44 & $-0.97^{* *}$ & 1.00 & & \\
\hline E & -0.36 & -0.39 & -0.25 & 0.09 & -0.33 & -0.20 & 0.26 & 0.30 & 0.47 & -0.31 & -0.27 & $-0.57^{*}$ & $-0.62^{*}$ & 0.47 & 1.00 & \\
\hline $\mathrm{D}_{\mathrm{m}}$ & 0.39 & 0.32 & 0.49 & 0.25 & 0.41 & 0.37 & -0.39 & $-0.57^{*}$ & $-0.52^{*}$ & 0.01 & -0.03 & $0.96^{* *}$ & -0.30 & 0.47 & $-0.52^{*}$ & 1.00 \\
\hline
\end{tabular}

Note: N, nitrogen; OC, organic carbon; P, soil phosphorus; K, soil potassium; Moi, moisture; RC, root colonization; SD, spore density; $\mathrm{R}$, richness; D, Simpson's index of dominance; $\mathrm{H}^{\prime}$, Shannon-Weiner indices of diversity; E, evenness; $\mathrm{D}_{\mathrm{m}}$, Margalef's richness index; ${ }^{* *}$, correlation is significant at $P<0.01$ level. , correlation is significant at $P<0.05$ level. Abbreviations are the same as in Table 9.

Table 9 Pearson's correlation between soil parameters and AMF diversity indices at T. arceuthoides stand

\begin{tabular}{|c|c|c|c|c|c|c|c|c|c|c|c|c|c|c|c|c|}
\hline & $\mathrm{N}$ & $\mathrm{OC}$ & $\mathrm{P}$ & $\mathrm{K}$ & Clay & Silt & Sand & $\mathrm{pH}$ & Moi & $\mathrm{RC}$ & SD & $\mathrm{R}$ & $\mathrm{D}$ & $\mathrm{H}^{\prime}$ & E & $\mathrm{D}_{\mathrm{m}}$ \\
\hline $\mathrm{N}$ & 1.00 & & & & & & & & & & & & & & & \\
\hline $\mathrm{OC}$ & $0.99^{* *}$ & * 1.00 & & & & & & & & & & & & & & \\
\hline $\mathrm{P}$ & 0.44 & 0.44 & 1.00 & & & & & & & & & & & & & \\
\hline K & $0.52^{*}$ & $0.52^{*}$ & 0.02 & 1.00 & & & & & & & & & & & & \\
\hline Clay & 0.33 & 0.34 & 0.28 & $0.56^{*}$ & 1.00 & & & & & & & & & & & \\
\hline Silt & 0.31 & 0.32 & 0.29 & $0.64^{*}$ & $0.73^{* *}$ & 1.00 & & & & & & & & & & \\
\hline Sand & -0.33 & -0.34 & -0.26 & $-0.68^{* *}$ & $-0.80^{* *}$ & $-0.99^{* *}$ & 1.00 & & & & & & & & & \\
\hline $\mathrm{pH}$ & 0.40 & 0.39 & -0.18 & 0.34 & -0.24 & -0.04 & 0.05 & 1.00 & & & & & & & & \\
\hline Moi & 0.003 & 0.01 & -0.21 & 0.14 & 0.33 & $0.59^{*}$ & $-0.55^{*}$ & -0.06 & 1.00 & & & & & & & \\
\hline $\mathrm{RC}$ & 0.15 & 0.14 & -0.22 & 0.41 & -0.14 & 0.14 & -0.14 & 0.24 & $0.78^{* *}$ & 1.00 & & & & & & \\
\hline $\mathrm{SD}$ & -0.27 & -0.26 & 0.27 & -0.15 & 0.38 & 0.13 & -0.16 & -0.36 & $-0.71^{* *}$ & -0.31 & 1.00 & & & & & \\
\hline $\mathrm{R}$ & 0.17 & 0.18 & -0.10 & 0.39 & 0.15 & 0.16 & -0.20 & 0.20 & 0.24 & $0.65^{* *}$ & -0.19 & 1.00 & & & & \\
\hline $\mathrm{D}$ & 0.08 & 0.08 & $0.66^{* *}$ & -0.18 & 0.11 & 0.07 & -0.05 & -0.41 & -0.29 & -0.32 & 0.40 & -0.25 & 1.00 & & & \\
\hline $\mathrm{H}^{\prime}$ & -0.03 & -0.02 & $-0.66^{* *}$ & 0.26 & -0.07 & -0.04 & 0.01 & 0.44 & 0.33 & 0.42 & -0.43 & 0.41 & $-0.98^{* *}$ & 1.00 & & \\
\hline E & -0.13 & -0.12 & $-0.53^{*}$ & 0.04 & -0.14 & -0.10 & 0.10 & 0.32 & -0.07 & -0.04 & -0.28 & -0.33 & $-0.82^{* *}$ & $0.71^{* *}$ & 1.00 & \\
\hline $\mathrm{D}_{\mathrm{m}}$ & 0.17 & 0.18 & -0.19 & 0.40 & 0.03 & 0.09 & -0.13 & 0.32 & 0.39 & $0.68^{* *}$ & -0.38 & $0.97^{* *}$ & -0.37 & $0.53^{*}$ & -0.18 & 1.00 \\
\hline
\end{tabular}

(Fokom et al., 2012; Vasconcellos et al., 2016), the present study has also demonstrated that AMF diversity could be a key factor for understanding soil quality. Furthermore, it should be reiterated that because fungi are able to adapt to local habitats and also because they are important for 
biodiversity conservation, AMF species should be carefully identified for each specific region (Symanczik et al., 2014).

Unlike other studies reporting that soil compaction did not affect AMF (Miransari, 2013; Thorne et al., 2013), the present study demonstrated that sand mining and truck movement did negatively affect AMF diversity and SD through reducing fine roots (Waltert et al., 2002). As shown earlier, sand mining caused approximately $24.4 \%$ and $10.8 \%$ reductions in SD in $P$. euphratica and T. arceuthoides, respectively. These results are in accordance with Jasper et al. (1991).

\section{Conclusions}

The present study found that disturbances by sand mining and truck movements in riparian forests negatively affected AMF diversity and root colonization rates. Although the study site was only 400 meters long, the results displayed a high spatial variation in AMF diversity, suggesting that the riparian forests are rather sensitive to anthropogenic activities. Furthermore, this present study show that soil moisture, clay, silt, sand, and $\mathrm{P}$ are among soil factors that can significantly change AMF communities both in the rhizospheres of $P$. euphratica and $T$. arceuthoides. In addition, the distances from the local riverbank also played a part in the variation of AMF diversity.

\section{Acknowledgements}

We thank Behbahan Khatam Al-Anbia University of Technology for its support during this study.

\section{References}

Ashraf M A, Maah M J, Yusoff L, et al. 2011. Sand mining effects, causes and concerns: A case study from Bestari Jaya, Selangor, Peninsular Malaysia. Scientific Research and Essays, 6(6): 1216-1231.

Beauchamp V B, Stromberg J C, Stutz J C. 2005. Interactions between Tamarix ramosissima (Saltcedar), Populus fremontii (Cottonwood), and mycorrhizal fungi: Effects on seedling growth and plant species coexistence. Plant and Soil, 275(1-2): 221-231.

Börstler B, Raab P A, Thiéry O, et al. 2008. Genetic diversity of the arbuscular mycorrhizal fungus Glomus intraradices as determined by mitochondrial large subunit rRNA gene sequences is considerably higher than previously expected. New Phytologist, 180(2): 452-465.

Bravard J P, Goichot M, Gaillot S. 2013. Geography of sand and gravel mining in the Lower Mekong River: First survey and assessment. EchoGéo, 26: 2-21.

Bremner JM, Mulvaney C S. 1982. Nitrogen total. In: Miller R H, Kieney D R. Method of Soil Analysis-part 2: Chemical and Microbiological Methods. Agronomy Series No. 9. American Society for Agronomy and Soil Sciences, Madison, 595-624.

Browicz K. 1977. Chorology of Populus euphratica Olivier. Arboretum Kórnickie, 22: 5-27.

Burton M L. 2006. Riparian woody plant diversity, composition, and structure across an urban-rural land use gradient in the piedmont of Georgia, US. PhD Dissertation. Alabama: Auburn University.

Byrnes M R, Hiland M W. 1995. Large-scale sediment transport patterns on the continental shelf and influence on shoreline response: St. Andrew Sound, Georgia to Nassau Sound, Florida USA. Marine Geology, 126(1-4): 19-43.

Caravaca F, Barea J M, Palenzuela J, et al. 2003. Establishment of shrub species in a degraded semiarid site after inoculation with native or allochthonous arbuscular mycorrhizal fungi. Applied Soil Ecology, 22(2): 103-111.

Chaudhary V B, Lau M K, Johnson N C. 2008. Macroecology of microbes—biogeography of the glomeromycota. In: Varma A. Mycorrhiza. Berlin: Springer, 529-563.

Colard A, Angelard C, Sanders I R. 2011. Genetic exchange in an arbuscular mycorrhizal fungus results in increased rice growth and altered mycorrhiza-specific gene transcription. Applied and Environmental Microbiology, 77(18): 6510-6515.

Deepika S, Kothamasi D. 2015. Soil moisture - a regulator of arbuscular mycorrhizal fungal community assembly and symbiotic phosphorus uptake. Mycorrhiza, 25(1): 67-75.

Fokom R, Adamou S, Teugwa M C, et al. 2012. Glomalin related soil protein, carbon, nitrogen and soil aggregate stability as affected by land use variation in the humid forest zone of south Cameroon. Soil \& Tillage Research, 120: 69-75.

Gerdemann J W, Nicolson T H. 1963. Spores of mycorrhizal Endogone species extracted from soil by wet sieving and decanting. Transactions of the British Mycological Society, 46(2): 235-244. 
Harris R, Kocher S D. 2007. Riparian Vegetation, Forest Stewardship Series 10, Davis, CA, University of California Agriculture and Natural Resources. UCANR Publication, 8240: 7.

Isebrands J G, Richardson J. 2014. Poplars and Willows: Trees for Society and the Environment. Boston, MA, USA: FAO and CABI, 656 .

Jasper D A, Abbott L K, Robson A D. 1991. The effect of soil disturbance on vesicular-arbuscular mycorrhizal fungi in soils from different vegetation types. New Phytologist, 118(3): 471-476.

Jha D K, Sharma G D, Mishra R R. 1992. Ecology of soil microflora and mycorrhizal symbionts in degraded forests at two altitudes. Biology and Fertility of Soils, 12(4): 272-278.

Kennedy A C, Papendick R I. 1995. Microbial characteristics of soil quality. Journal of Soil and Water Conservation, 50(3): 243-248.

Lambin E F, Geist H J, Lepers E. 2003. Dynamics of land-use and land-cover change in tropical regions. Annual Review of Environment and Resources, 28(1): 205-241.

Lara-Pérez L A, Noa-Carrazana J C, López Áde J, et al. 2014. Colonization and structure of arbuscular mycorrhizal fungi community in Alsophila firma (Cyatheales: Cyatheaceae) from a tropical montane cloud forest in Veracruz, México. Revista de Biología Tropical, 62(4): 1609-1623. (in Spanish)

Lawal P O. 2011. Effects of sand/gravel mining in Minna emirate area of Nigeria on stakeholders. Journal of Sustainable Development, 4(1): 193-199.

Lehnhoff E A, Rew L J, Zabinski C A, et al. 2012. Reduced impacts or a longer lag phase? Tamarix in the Northwestern U.S.A. Wetlands, 32(3): 497-508.

Li L F, Zhang Y, Zhao Z W. 2007. Arbuscular mycorrhizal colonization and spore density across different land-use types in a hot and arid ecosystem, Southwest China. Journal of Plant Nutrition and Soil Science, 170(3): 419-425.

Magurran A E. 2004. Measuring Biological Diversity. Oxford: Blackwell Publishing, 72-99.

Mahecha-Vásqueza G, Sierra S, Posada R. 2017. Diversity indices using arbuscular mycorrhizal fungi to evaluate the soil state in banana crops in Colombia. Applied Soil Ecology, 109: 32-39.

McCune B, Mefford M J. 1999. Multivariate Analysis of Ecological Data (4 ${ }^{\text {th }}$ ed.). Oregon, USA: MJM Software, Gleneden Beach, 237.

Miransari M, Bahrami HA, Rejali F, et al. 2007. Using arbuscular mycorrhiza to reduce the stressful effects of soil compaction on corn (Zea mays L.) growth. Soil Biology \& Biochemistry, 39: 2014-2026.

Mirzaei J, Moradi M. 2017. Biodiversity of arbuscular mycorrhizal fungi in Amygdalus scoparia Spach plantations and a natural stand. Journal of Forestry Research, 28: 1-9.

Moradi M, Shirvany A, Matinizadeh M, et al. 2015. Arbuscular mycorrhizal fungal symbiosis with Sorbus torminalis does not vary with soil nutrients and enzyme activities across different sites. iForest-Biogeosciences and Forestry, 8(3): 308-313.

Moradi M, Naji H R, Imani F, et al. 2017. Arbuscular mycorrhizal fungi changes by afforestation in sand dunes. Journal of Arid Environments, 140: 14-19.

Morwin H D, Peach P M. 1951. Exchangeability of soil potassium in and, silt and clay fractions as influenced by the nature of complementary exchangeable cations. Soil Science Society of America Journal, 15: 125-128.

Naiman R J, Bilby R E, Bisson P A. 2000. Riparian ecology and management in the Pacific coastal rain forest. BioScience, 50(11): 996-1011.

Oehl F, Jansa J, Ineichen K, et al. 2011. Arbuscular mycorrhizal fungi as bio-indicators in Swiss agricultural soils. Agrar Forschung Schweiz, 2: 304-311.

Olsen S R, Cole C V, Watanabe F S, Dean L A. 1954. Estimation of available phosphorus in soils by extraction with sodium bicarbonate. USDA Circular, 939: 1-19.

O'Neill E G, O'Neill R V, Norby R J. 1991. Hierarchy theory as a guide to mycorrhizal research on large-scale problems. Environmental Pollution, 73(3-4): 271-284.

Padmalal D, Maya K, Sreebha S, et al. 2008. Environmental effects of river sand mining: a case from the river catchments of Vembanad Lake, Southwest coast of India. Environmental Geology, 54(4): 879-889.

Piraino S, Fanelli G, Boero F. 2002. Variability of species' roles in marine communities: change of paradigms for conservation priorities. Marine Biology, 140(5): 1067-1074.

Power M E, Mills L S. 1995. The keystone cops meet in Hilo. Trends in Ecology \& Evolution, 10(5): 182-184.

Quoreshi A M. 2008. The use of mycorrhizal biotechnology in restoration of disturbed ecosystem. In: Siddiqui Z A, Akhtar M S. Mycorrhizae: Sustainable Agriculture and Forestry. Dordrecht: Springer, 303-320.

Sakio H, Tamura T. 2008. Ecology of Riparian Forests in Japan: Disturbance, Life History, and Regeneration. Tokyo: Springer, 339. 
Schenck N C, Perez Y. 1988. Manual for identification of vesicular-arbuscular mycorrhizal fungi. INVAM, University of Florida, Gainesville, Florida, USA, 241.

Schüßler A, Schwarzott D, Walker C. 2001. A new fungal phylum, the Glomeromycota: phylogeny and evolution. Mycological Research, 105(12): 1413-1421.

Shi Z Y, Zhang L Y, Feng G, et al. 2006. Diversity of arbuscular mycorrhizal fungi associated with desert ephemerals growing under and beyond the canopies of Tamarisk shrubs. Chinese Science Bulletin, 51(Suppl.): 132-139.

Smith S E, Read D J. 2008. Mycorrhizal Symbiosis ( $3^{\text {rd }}$ ed.). San Diego: Academic Press, 13-41.

Soka G, Ritchie M. 2014a. Arbuscular mycorrhizal symbiosis and ecosystem processes: prospects for future research in tropical soils. Open Journal of Ecology, 4(1): 11-22.

Soka G, Ritchie M. 2014b. Arbuscular mycorrhizal symbiosis, ecosystem processes and environmental changes in tropical soils. Applied Ecology and Environmental Research, 13(1): 229-245.

Sreebha S, Padmalal D. 2011. Environmental impact assessment of sand mining from the small catchment rivers in the southwestern coast of India: A case study. Environmental Management, 47(1): 130-140.

Strasser T, Lang S, Blaschke T. 2014. Class modelling of complex riparian forest habitats. South-Eastern European Journal of Earth Observation and Geomatics, 3(2S): 531-534.

Stürmer S L, Siqueira J O. 2011. Species richness and spore abundance of arbuscular mycorrhizal fungi across distinct land uses in Western Brazilian Amazon. Mycorrhiza, 21(4): 255-267.

Symanczik S, Blaszkowski J, Koegel S, et al. 2014. Isolation and identification of desert habituated arbuscular mycorrhizal fungi newly reported from the Arabian Peninsula. Journal of Arid Land, 6(4): 488-497.

Thorne M., Rhodes L, Cardina J. 2013. Soil compaction and arbuscular mycorrhizae affect seedling growth of three grasses. Open Journal of Ecology, 3(7): 455-463.

Tockner K, Stanford J A. 2002. Riverine flood plains: present state and future trends. Environmental Conservation, 29(3): 308-330.

Trejo D, Barois I, Sangabriel-Conde W. 2016. Disturbance and land use effect on functional diversity of the arbuscular mycorrhizal fungi. Agroforestry Systems, 90(2): 265-279.

Treseder K K. 2004. A meta-analysis of mycorrhizal responses to nitrogen, phosphorus and atmospheric $\mathrm{CO}_{2}$ in field studies. New Phytologist, 164: 347-365.

Van Der Heijden M G A, Bardgett R D, Van Straalen N M. 2008. The unseen majority: soil microbes as drivers of plant diversity and productivity in terrestrial ecosystems. Ecology Letters, 11(3): 296-310.

Vasconcellos R L F, Bonfim J A, Baretta D, et al. 2016. Arbuscular mycorrhizal fungi and glomalin-related soil protein as potential indicators of soil quality in a recuperation gradient of the Atlantic Forest in Brazil. Land Degradation \& Development, 27(2): 325-334.

Verbruggen E, Van Der Heijden M G, Weedon J T, et al. 2012. Community assembly, species richness and nestedness of arbuscular mycorrhizal fungi in agricultural soils. Molecular Ecology, 21(10): 2341-2353.

Walkley A, Black I A. 1934. An examination of Degtjareff method for determining soil organic matter and a proposed modification of the chromic acid titration method. Soil Science, 37: 29-37.

Wallace L L. 1987. Effects of clipping and soil compaction on growth, morphology and mycorrhizal colonization of Schizachyrium scoparium, a $\mathrm{C}_{4}$ bunchgrass. Oecologia, 72(3): 423-428.

Waltert B, Wiemken V, Rusterholz H P, et al. 2002. Disturbance of forest by trampling: effects on mycorrhizal roots of seedlings and mature trees of Fagus sylvatica. Plant and Soil, 243(2): 143-154.

Wang Y S, Chen L, Zhang S B, et al. 2010. Biodiversity of arbuscular mycorrhizal fungi in the natural forests of Populus euphratica and Alhagi sparsifolia in Xinjiang. Arid Zone Research, 27(6): 927-932. (in Chinese)

Yang H, Yuan Y, Zhang Q. et al. 2011. Changes in soil organic carbon, total nitrogen, and abundance of arbuscular mycorrhizal fungi along a large-scale aridity gradient. Catena, 87: 70-77.

Yang Y H, Chen Y N, Li W H. 2008. Arbuscular mycorrhizal fungi infection in desert riparian forest and its environmental implications: A case study in the lower reach of Tarim River. Progress in Natural Science, 18(8): 983-991.

Yang Y H, Chen Y N, Cai B Y, et al. 2013. The arbuscular mycorrhizal symbiotic status of Populus euphratica, a drought resistant tree species from arid lands. Ecohydrology, 6(6): 1001-1008.

Yoshimura Y, Ido A, Iwase K, et al. 2013. Communities of arbuscular mycorrhizal fungi in the roots of Pyrus pyrifolia var. culta (Japanese Pear) in orchards with variable amounts of soil-available phosphorus. Microbes Environ 28: 105-111. 